\title{
Türkiye'de Tarımsal İstihdamın Cinsiyete Dayalı Yapısı ve Sosyal Politika Önerileri
}

\begin{abstract}
Türkiye'de Tarımsal İstihdamın Cinsiyete Dayalı Yapısı ve Sosyal Politika Önerileri

Öz

Tarımsal istihdam, Türkiye'deki istihdamın temel itici gücü olmasına rağmen, 2000 yılından itibaren istihdamın ağırlıklı olarak tarımdan hizmet sektörüne kaydığı görülmektedir. Ancak, tarım sektöründeki istihdamın Türkiye'nin toplam istihdamı içindeki payı (yaklaşık 5'te bir), tarımsal istihdamın hala önemini koruduğunu göstermektedir. Bu açıdan bu çalışma, Türkiye Hanehalkı İşgücü Anketi mikro verilerine kontenjans tablolama ve Ki-kare analiz yöntemini kullanarak, Türkiye'de tarımsal istihdam ile demografik ve istihdamla ilgili değişkenler arasındaki ilişkide, cinsiyet farklılıklarını incelemeyi ve elde edilen bulgular ışığında politika yapıcılar için bazı sosyal politika önerilerinde bulunmayı amaçlamaktadır. Çalışmanın sonuçları, tarımda istihdam edilen kadınların oranının erkeklerden daha yüksek olmasına rağmen, istihdam edilen kadınların ücretsiz aile işçiliği, kısmi süreli, geçici veya sınırlı süreli çalışma ve kayıt dışı istihdamı içeren güvencesiz istihdam biçimlerinden erkeklere kıyasla çok daha fazla etkilendiğini ortaya koymaktadır.
\end{abstract}

Anahtar Kelimeler: Türkiye'de Tarım Sektörü, Tarımsal İstihdam, Sosyal Politika.
Ayhan Görmüş ${ }^{1}$

Gender-based Structure of Agricultural Employment in Turkey and Social Policy Proposals

Abstract

Although agricultural employment is the main driver of employment in Turkey, since 2000, it has been seen that employment predominantly shifts from agriculture to the services sector. However, the proportion of employment in the agriculture sector to Turkey's total employment (almost 1 in 5) displays that agricultural employment has still been of its importance. In this regard, this study aims to examine the gender differences in the relationship between agricultural employment and the demographic and work-related variables, by using contingency tabulation and Chi-square analysis method to the microdata from Turkish Labour Force Survey, and suggest some social policies for policy-makers in light on the findings obtained. The results of the paper reveal that although the proportion of women in agricultural employment is higher than that of men, women employed are far more affected by precarious employment forms including unpaid family worker, part-time, temporary or limited time working and informal employment, compared to men.

Keywords: Agriculture Sector in Turkey, Agricultural Employment, Social Policy.

\section{Giriş}

Tarihsel süreçte, tarımın ulusal gelire ve istihdama egemen olduğu ekonomik kalkınmanın ilk aşamalarında, tarım sektörünün ve özellikle gıda sektörünün, ekonomik kalkınma üzerinde önemli bir rolü olmuştur. Ancak zaman içerisinde, sanayileşme ve bilgi ekonomisi ekonomik kalkınmanın temel dinamiği haline geldikçe, tarım sektörünün genel ekonomi içindeki payı nispeten daha küçülmüş ve kalkınma üzerindeki etkisi giderek azalmıştır. Diğer taraftan, yer altı zenginlikleri veya diğer endüstriyel mal üretimi daha sınırlı olmasına rağmen, daha iyi tarımsal ekolojik koşullara sahip ülkelerde, tarımın ekonomik kalkınmadaki rolü önemini korumaktadır. Ayrıca, küçük çiftliklerin egemen olduğu ülkelerde tarım sektörü ekonomik kalkınmadaki ağırığını sürdürüyorken, dinamik ve sürekli büyüyen ulusal ekonomileri ve yüksek kişi başına düşen geliri olan ülkeler, daha yüksek katma değerli ürünleri ve tarım dışı gelir kaynakları çeşitlendirme açısından, çiftçilere daha fazla fırsat sunmaktadır. Bunun aksine, daha fakir ve daha yavaş büyüyen ekonomilerde ise, gelir çeşitliliği ve çıkış stratejilerine yönelik fırsatlar daha sınırlı kalmaktadır (Diao vd., 2010:1376). Bununla birlikte, gelişmekte olan

\footnotetext{
${ }^{1}$ Doç. Dr., Tekirdağ Namık Kemal Üniversitesi, Çalışma Ekonomisi ve Endüstri illişkileri Bölümü, agormus@nku.edu.tr Yazar ORCID bilgisi:, https://orcid.org/0000-0002-6175-5381
} 
ülkelerin kırsal bölgelerindeki kalkınmanın temel itici gücü, büyük ölçüde tarım sektörüdür. Birleşmiş Milletler Gıda ve Tarım Örgütü (FAO) tahminlerine göre, dünya genelinde tarımda yaklaşık 1,3 milyar insan çalışmakta ve bunların \%97'si gelişmekte olan ülkelerde bulunmaktadır. Bu açıdan, bölgelere göre değişmekle birlikte, gelişmekte olan ülkelerin kırsal kesimlerindeki hane gelirinin \%30 ila 50'si doğrudan tarımdan elde edilmektedir (Fechter, 2012:1).

Gelişmiş ve gelişmekte olan ülkelerde, sosyo-ekonomik olarak önemini koruyan tarım sektörüne yönelik hatırı sayılır miktarda literatür birikmiştir. Tarıma sosyo-ekonomik açıdan bakan bu literatürün önemli bir kısmı, bölgesel kalkınma veya kırsal kalkınma, kırsal yoksulluk ve tarımda çocuk işçiliği odaklı olup, tarımsal istihdama yönelik analitik çalışmaların sayıca daha sınırlı olduğu görülmektedir. Türkiye özelinde de tarım sektörünü sosyo-ekonomik olarak inceleyen çalışmalara bakıldığında, durum benzer olup, tarımsal istihdama yönelik yapılan araştırmaların, özellikle ampirik çalışmaların, oldukça az olduğu göze çarpmaktadır. Bu çalışmalara bazı örnekler vermek gerekirse, Karacan'ın (1991) Manisa örnekleminde yaptığı çalışmasında, geçici tarım iş̧̧ilerinin çalışma koşullarını, eğitim, ekonomik ve demografik durumlarını ve iş bulma yöntemlerini, sağlık ve iş güvenliği durumlarını, ücretlerini ve sosyal güvenlik durumlarını işçiler, işverenler ve aracıların bakış açılarına göre, yüz yüze anket yöntemini kullanarak incelemiştir. Araştırma kapsamında sezonda sadece 3 ay çalışabilen geçici tarım işçilerinin \%60'ının kadın, \%23,9'unun 16 yaş altı çocuk çalışandan oluştuğu, günlük çalışma süresinin haftanın 7 günü, günlük 11 saatin üzerine çıkabildiği, ücretin toplanan ürün kilogramı bazında belirlendiği ve \%93'ünün sosyal güvenceden yoksun olduğu sonucuna ulaşılmıştır (Karacan, 1991:65-67). Makal (2001) ise, 1950-1965 yıllarını kapsayan dönemsel çalışmasında, tarım kesiminde Türkiye'de işgücü ve ücretli emekle ilgili yaşanan gelişmeleri eleştirel boyuttan ele almıştır. Makal, çalışmasında 1950'li yıllarda yaşanan değişimlerin, ekilen tarım alanlarının sınırlarına ulaşması ve tarımsal makina ve girdi kullanımındaki artışların tarımsal işgücü ihtiyacını azaltarak, özgürleşmiş bir işgücü tabakasının doğmasına yol açtığı gibi, mevsimlik işlerde çalışan sayısını artırdığı ve zamanla köyden kente göçe dönüştüğü sonucuna ulaşmıştır (Makal, 2001:137). Türkiye'de tarım sektöründe işgücü piyasasını, istihdamın yapısal durumunu inceleyen Işın ve arkadaşları (2010), çalışmalarında tarım sektöründe çalışanlara yönelik sosyal güvenlik politikalarını irdelemeyi amaçlamıştır. 1990-2000-2008 dönemleri Tüik, Sosyal Güvenlik Kurumu ve Devlet Planlama Teşkilatı verilerinin değerlendirildiği çalışmada, Türkiye'de kırsal kesimde istihdam edilen ve genel olarak daha düşük eğitim ve gelir düzeyine sahip nüfusun $\% 60,8^{\prime}$ inin tarımsal faaliyetle uğraştıkları, ancak tarımın istihdamdaki oranının giderek azaldığı, tarımsal istihdamın \%92,4'ünün kendi hesabına çalışan ve ücretsiz aile işçilerinden oluştuğu ve yaklaşık \%73,4'ünün sosyal güvenlik kapsamında olmadığı sonucuna ulaşılmıştır (Işın vd., 2010:1). Gülçubuk (2012) Adana'nın Karataş ilçesinde yürüttüğü araştırma projesinde, tarımda çocuk işçiliğini ve çalışma yaşamındaki yerini uluslararası sözleşmeler bağlamında ele almıştır. Bu projede, Türkiye'de 15 yaşından küçük çocuk çalışanların \%40 ila 50'sinin tarımda çalıştırıldığına dikkat çekilerek, ILO sözleşmelerine göre çalışma çağında olmayan ve özellikle Güneydoğu ve Doğu Anadolu Bölgeleri'nde yılın 4 ila 7 ayını çadırlarda temel gereksinimlerden yoksun olarak geçiren bu çocukların eğitimden yoksun bırakıldığı vurgulanmıştır (Gülçubuk, 2012:75). Demir (2015), mevsimlik tarım çalışanlarına yönelik sosyal güvenlik düzenlemelerini incelediği çalışmasında, bu alanda yapılan düzenlemelerin başarısız kaldığını ve yeni yasal düzenlemelerin mevsimlik tarım işçilerinin ihtiyaçlarını karşılamaktan oldukça uzak olduğunu ileri sürmüştür. Alkan (2015) ise, çalışmasında Türkiye'de tarımsal işletmelerde çalışanların ücretleri ile işgücüne katılma oranları arasındaki ilişkinin varlığını, önemini ve boyutunu ekonometrik bir model kullanarak analiz etmiştir. Bu çalışmada, tarım 
sektöründe işgücüne katılım oranı ile ücretler arasında küçük de olsa bir ilişkinin olduğu ve ücretlerdeki bir birimlik artışın işgücüne katılım oranını sıfır ya da sıfıra yakın bir düzeyde etkilediği sonucuna ulaşılmıştır (Alkan, 2015:169). Yapılan bu ve benzeri çalışmalara bakarak, tarım sektöründeki istihdamı arz yanlı yaklaşımlarla cinsiyet farklılıklarını ele alan çalışmalardaki eksiklik, bu konunun akademik olarak incelenmesini ve tartışımasını daha önemli kılmaktadır. Bu çerçevede, tarımsal istihdam alanında literatüre katkı sağlamak amacıyla bu çalışmanın cevap arayacağı sorular şunlardır: Demografik ve istihdamla ilgili değişkenler ile tarımsal istihdam ilişkisi, cinsiyete göre nasıl farklılaşıyor? Tarımsal istihdamın kullanılan değişkenler bakımından emek arzı sorunları neler ve bu sorunlar cinsiyetlere göre farklılaşıyor mu? Tarımsal istihdamla ilgili tespit edilecek sorunlara yönelik hangi sosyal politikalar uygulanabilir? Bu araştırma sorularını cevaplamak için, bu çalışmada TÜik'in 2016 yılı Hanehalkı İşücü Anketi (HiA) mikro verilerine Ki kare bağımsızlık testi uygulayarak, tarımsal istihdam ile demografik ve istihdamla ilgili değişkenler ilişkisinde, cinsiyet farklılıkları analiz edilecektir. Ayrıca, elde edilen sonuçlardan yola çıkarak, tarımın demografik ve istihdamla ilgili sorunları tespit edilip, bu sorunlara yönelik bir takım sosyal politikalar önerilecektir.

Çalışmanın bundan sonraki kısımları, "Türkiye'de tarımın makroekonomik seyri", "araştırmanın yöntemi" ve son olarak analiz sonuçlarının değerlendirildiği ve sosyal politika önlemlerinin tartışıldığı "sonuç" bölümlerinden oluşmaktadır.

\section{Türkiye'de Tarımın Makroekonomik Seyri}

Tarım sektörünün, yalnızca bitkisel ve hayvansal üretim faaliyetleri ile nüfusun ihtiyaç duyduğu gıda ve diğer tarımsal ürünlerin tedarik edilmesi süreci olarak görülmesi hatalıdır (Erkuş vd., 2005). Tarıma dayalı ekonomiden sanayiye dayalı bir ekonomiye geçiş aşamasında, tarım sektörünün nüfusun gıda ihtiyacını karşılamasının yanı sıra, döviz girdisine katkı sağlamak üzere bir üretim fazlası oluşturmak, diğer sektörlere sermaye ve işgücü transfer etmek ve sanayi malları için talep oluşturmak gibi başka fonksiyonları da bulunmaktadır (Cinemre ve Kılıç, 2011). Türkiye açısından bakıldığında, tarımın genel ekonomi içindeki nispi payı önemli ölçüde azalmış olmakla birlikte, nüfusun gıda ihtiyacına, sanayi sektörüne hammadde teminine, döviz ihtiyacına ve istihdama yaptığı katkı açısından, tarım sektörünün hala önemini koruduğu görülmektedir (ÇSGB, 2017:65).

Grafik 1. Tarımın GSYiH içindeki payı ve tarımda büyüme ve istihdam artış hızı

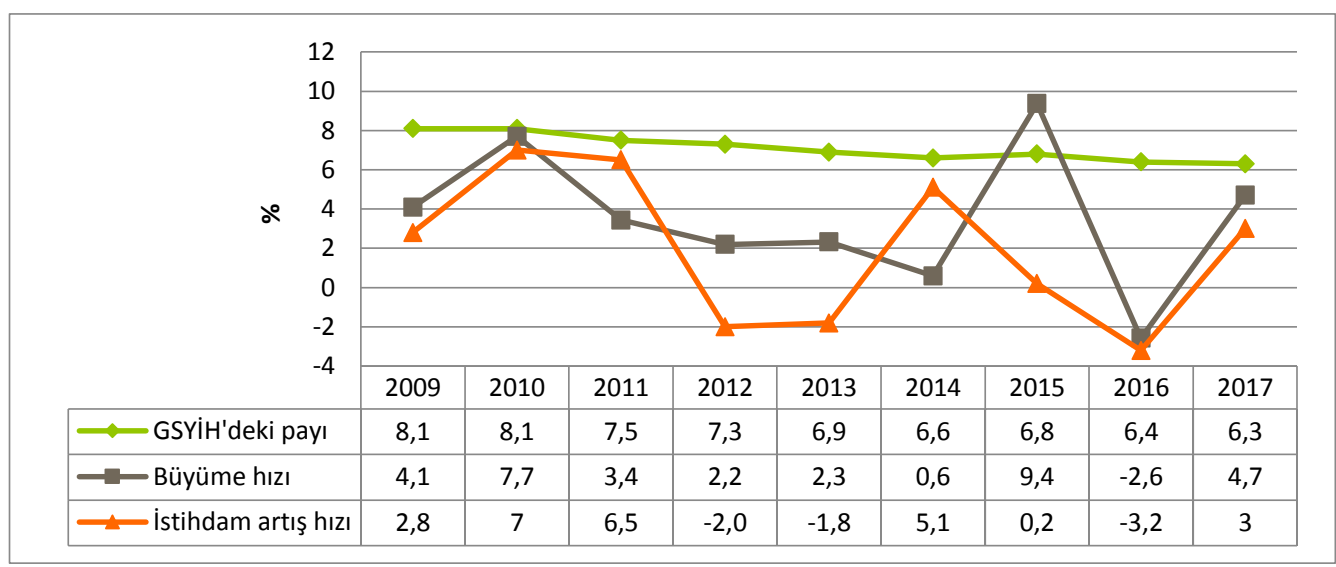

Kaynak: TÜiK, 2018a

Not: İstihdam artış hızı yazar tarafından hesaplanmıştır. 
Grafik 1 incelendiğinde, tarım sektörünün GSYiH içindeki payının giderek düştüğü izlenmektedir. TÜik verilerine göre, 2009 yılında tarımın GSYiH içindeki payı \%8,1'iken, 2017 yılında bu oran \%6,3'e gerilemiştir. Tabi ki, tarımın GSYiH içindeki payının azalmasını sadece ekonomik gelişmeye bağlamak doğru bir yaklaşım değildir. Bunun altında yatan esas sebep, tarımdaki gelir artış hızının, diğer sektörlere göre, daha yavaş olmasıdır. Yani, tarımsal üretim ve ürün fiyatları diğer sektörlere kıyasla daha yavaş artmakta ve tarımsal ürünlerin değer artışları, diğer sektörlerin görece altında kalmaktadır (Doğan vd., 2015:35; Kıral ve Akder, 2000:12).

Grafik 1'de tarımdaki büyüme hızlarında yıllar içerisinde artan ve azalan trendler izlenmekle birlikte, genel olarak bir azalma eğilimi görülmektedir. Buna göre, tarımdaki büyüme hızı $2010(\% 7,7)$ ve $2015(\% 9,4)$ yıllarında önemli sıçrayışlar yapmasına rağmen, 2010-2014 periyodunda lineer bir azalmadan sonra, 2016 (\%-2,6) yılında negatife dönmüştür. Grafik 1'de, 2009 küresel ekonomik krizin etkili olduğu 2009-2012 periyodunda, tarımdaki büyüme ve istihdam hızlarının arttığı açıkça görülebilmektedir. Tüik verilerine göre, Türkiye 2009-2017 yılları arasında yıllık ortalama \%5,5 büyürken, aynı dönem içerisinde tarım sektörü yıllık ortalama \%3,5 oranında büyüyerek, Türkiye ortalamasının yaklaşık 2 puan gerisinde kalmıştır. Çalışma ve Sosyal Güvenlik Bakanlığı'nın (ÇSGB) Ulusal İstihdam Stratejisi (UiS) belgesinde (2017), tarımsal büyüme hızındaki bu düşüş trendinin, Türkiye'de sanayi ve hizmet sektörlerinin tarım sektörüne kıyasla nispi olarak daha hızlı gelişmesinden kaynaklandığı ileri sürülmüştür.

Grafik 1'e bakıldığında, tarımdaki istihdam artış hızının da tarımsal büyüme hızı paralelinde hareket ettiği görülmekle birlikte, yıllar içerisinde bir düşme eğilimi gözlenmektedir. Tarımdaki istihdam hızı sadece $2011(\% 6,5)$ ve $2014(\% 5,1)$ yıllarında büyüme hızının üzerine çıkarken, 2010-2014 dönemindeki ve 2016'daki tarımsal büyüme hızında yaşanan düşme eğilimi, 2012 (\%-2), 2013 (\%-1,8) ve 2016 (\%-3,2) yıllarında tarımsal istihdam hızının negatife dönmesine yol açmıştır. Bu düşüşte hiç şüphesiz Türkiye'deki 1980 sonrası yaşanan neo-liberalleşmenin önemli bir payı vardır. Dış ticaret serbestliği, korumacı politikaların bırakılması, uluslararası anlaşmalar ve özelleştirmeler ${ }^{2}$ ile kendini gösteren bu süreçten en çok etkilenen kesimlerden biri de tarım sektörü olmuştur. Bütün bu faktörlerin hepsi, kırsalda yaşayan nüfusu yoksulluğa, işsizliğe, kırdan kente göçe ve sigortasız çalışmaya itmektedir (Sındır, 2008). Bu yüzden, Türkiye'de kentte yaşan nüfus yoğunluğu giderek artarken, kırda yaşayan nüfus yoğunluğu giderek düşmektedir.

Gelişmiş ülkelerde tarımsal istihdam, toplam istihdamın küçük bir bölümünü oluşturmasına rağmen, önemli ölçüde desteklendiğinden, tarım sektörünün gelişmiş ülke ekonomilerinde hala önemli bir yeri vardır. Aynı zamanda, bu ülkelerde işgücünün bu kadar küçük bir bölümünün ülkenin gıda ihtiyacının çoğunluğunu karşılama yeteneği, tarım sektörünün kabiliyet ve verimliliğini kanıtlamaktadır. Ancak, tarımsal istihdam çiftlik sayısı, büyüklüğü ve ölçeğindeki dönüşümlerden önemli ölçüde etkilenmiştir. Tarım teknolojisi geliştikçe, sermaye ekipmanlarının daha yoğun kullanımı ile istihdam emek gücünden makineye doğru kaymıştır. Son yıllarda, bu yapısal ve teknolojik değişikliklerin tarımsal işler üzerinde büyük bir etkisi olmuş ve hem tarımsal işgücünün karakteristiğini, hem de miktarını etkileyerek tarımsal istihdamda bir azalmaya yol açmıştır (Daly, 1981:11). Geleneksel olarak, kırsal bölgelerdeki istihdamı önemli ölçüde absorbe eden tarımsal istihdamda yaşanan bu azalma eğiliminin gelecek yıllarda da

\footnotetext{
${ }^{2}$ Bu politikalar kapsamında örneğin, daha yakın dönemde Türkiye'de kamuya ait 14 şeker fabrikasının özelleştirilmesi gerçekleştirilmiştir.
} 
devam etmesi beklenmektedir. Tarımsal istihdamda yaşanan bu düşüş, tarımın toplam istihdam içindeki payının yüksek olduğu ve yeterli alternatif iş olanaklarının bulunmadığı kırsal bölgelerin sosyo-ekonomik durumunu olumsuz yönde etkilemektedir (Schwarcz vd., 2012:483).

Az gelişmiş ülkelerdeki çalışanların çoğunluğu, aylık ücretli bir işe giremedikleri için daha çok kendi hesabına veya ücretsiz aile iş̧̧isi olarak tarımla ve özellikle de geçimlik tarımla uğraşmaktadırlar. 2000 yılına kadar tarım, dünya çapında istihdamın temel itici gücü olmasına rağmen, bu tarihten sonra istihdam, ağırlıklı olarak hizmetler sektörüne doğru kaymış ve bu iki sektör arasındaki fark hizmetler lehine giderek açılmıştır. Ancak, tarımdaki istihdam artışı her ne kadar yavaşlasa da, bu sektördeki çalışan sayısı 2009'da 1 milyardan fazlaydı (tüm çalışanların 1/3'ü). Özellikle Sahra-altı Afrika'da bu oran \%60'a kadar çıkmaktadır. 1999 ve 2009 yılları arasında Afrika'da tarımsal istihdamdaki büyüme, tüm istihdam artışlarının yarısını oluşturuyorken, Güney Asya'da sağlanan istihdam artışının yaklaşık \%33'ü, tarım sektöründe gerçekleşmiştir. Buna karşılık, gelişmiş ekonomiler, Doğu Asya, Latin Amerika ve Karayip bölgelerinde tarımsal istihdam giderek düşme eğilimindedir. Küresel düzeyde bakıldığında, tarım sektöründe kadınların (\%38) erkeklerden (\%33) daha aktif olduğu görülmektedir (FAO, 2012:18).

Son yıllarda, tarımda sanayileşme ve makineleşme ile birlikte istihdamda yaşanan azalma eğilimi, gecikmeli de olsa, Türkiye'de de yaşanmaktadır. Tarımda teknoloji kullanımının artmasının yanı sıra, işlenen tarımsal alanların girerek daralması (Tan vd., 2015:589), miras yoluyla arazilerin parçalanması ve tarım işletmelerinin küçülmesi tarımı olumsuz yönde etkilemiştir. Böylece Türkiye'de tarım artık işgücünü çeken değil, iten bir sektör haline gelmiştir. Ancak, Türkiye gibi istihdamın yaklaşık \%20'sinin tarımda istihdam edildiği bir ülkede, sektörler arası ilişkiler, gıda güvenliği ve güvencesi ile istihdam açısından, tarım hala önemini muhafaza etmektedir (Gülçubuk vd., 2005:1). Yani, Türkiye'de tarımın nüfusa ve istihdama, beslenmeye, yurt içi tüketime, sanayiye, milli gelire ve ödemeler dengesine, biyolojik çeşitliliğe ve ekolojik dengeye olan önemli katkıları düşünüldüğünde, göz ardı edilmesi mümkün olmayan bir sektördür (Tan vd., 2015:588; Yıldız vd., 2017:10).

1980 'li yıllarda yaşanan liberalleşmeyle beraber, Türkiye tarım toplumundan sanayi toplumuna geçişi tamamlayamadan bilgi toplumunun yapısal sorunlarıyla karşı karşıya kalmıştır. Bu sosyo-ekonomik dönüşüm sürecinde, Türkiye'de istihdamın sektörel yoğunluğu tarım sektöründen hizmetler sektörüne doğru kaymıştır. Tarımsal istihdamdaki bu değişim, tarım toplumundan sanayi toplumuna geçişin bir göstergesi olarak kabul edilmesine (ÇSGB, 2017:65) rağmen, "sağlıklı bir dönüşüm" olarak kabul edilmemektedir (Sapancalı, 2007:13). 
Grafik 2. Istihdam oranlarının sektörlere göre dağılımı

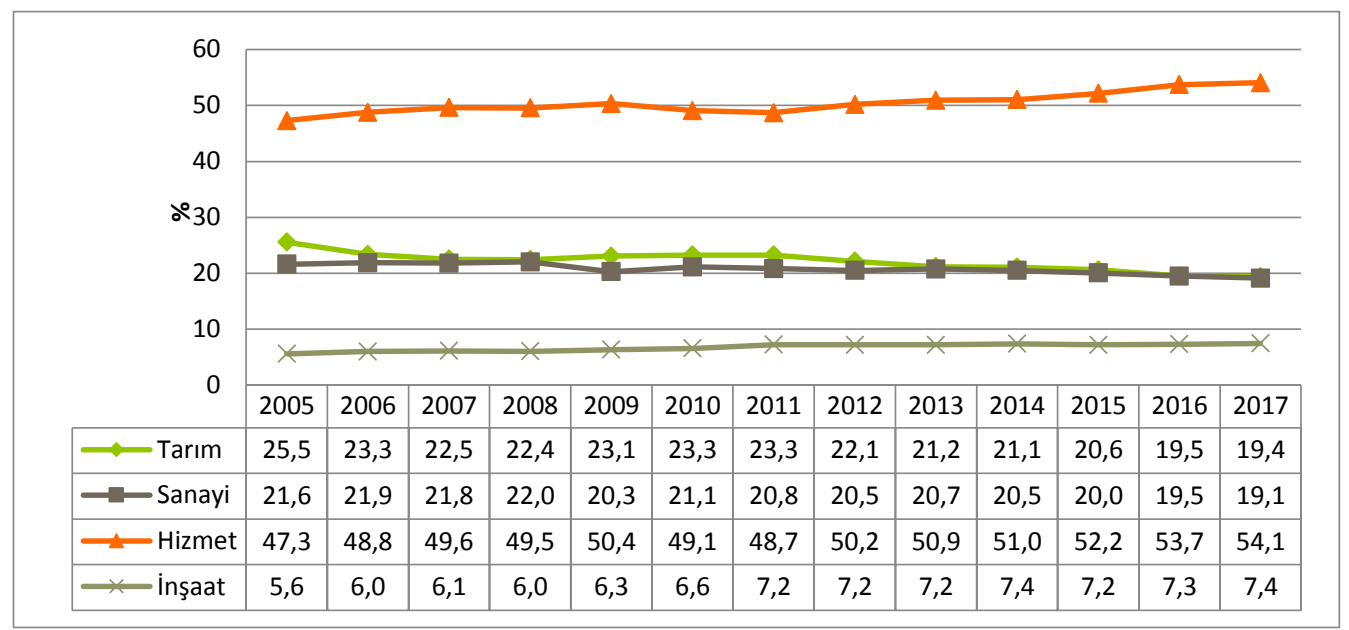

Kaynak: TÜiK, 2018a

Grafik 2'de yıllar itibariyle, Türkiye'de istihdam oranlarının sektörlere göre dağılım seyri gösterilmektedir. Grafik detaylı incelendiğinde, 2005-2017 periyodunda tarım ve sanayi sektörlerinde istihdam oranlarında bir gerileme gözlemlenirken, hizmetler ve inşaat sektörlerinde ise, simetrik olarak bir artış izlenmektedir. Bu açıdan, 2017 yılı itibariyle tarımsal istihdam oranı \%19,4'e ve sanayi istihdam oranı \%19,1'e inerken, hizmetlerdeki istihdam oranı \%54,1'e ve inşaattaki istihdam oranı ise, \%7,4'e yükselmiştir. Ayrıca, Grafik 1'i de dikkate alarak, 2017 'de toplam istihdamın \%19,4'ü ile GSYIH'nın yalnızca \%6,3'ünü üretebilen tarım sektöründe bir verimlilik sorununun olduğunu da söyleyebiliriz.

2005-2017 dönemi incelendiğinde, en çok düşüşün görüldüğü tarım sektöründeki yaklaşık \%6'lık daralma, hizmetler sektöründeki yaklaşık \%7'lik ve inşaat sektöründeki yaklaşık \%2'lik istihdam genişlemesi ile ikame edilmiş gibi gözükmektedir. Böylece, tarımdan kayan istihdamın önemli bir bölümünün hizmetler sektörü ile geri kalan daha az bir kısmının inşaat sektörü arasında paylaşıldığını söyleyebiliriz. Tarımsal istihdam oranlarının yıllar içerisinde izlediği seyir dikkate alındığında, 2005-2008 döneminde düzenli şekilde azalan tarımsal istihdam oranı, 2009 ve 2011 yıllarında hafif bir artış trendine girerek, \%23,3'e kadar yükselmiştir. Bu dönemdeki tarımsal istihdamdaki artışın sebebini 2009 küresel ekonomik krize bağlamak mümkündür. Zira krizin etkilerinin hafiflemeye başladığı 2011'den itibaren tarımsal istihdam yeniden bir daralma trendine girerek, 2017 itibariyle \%19,4 kadar gerilemiştir. Bu durum bize ekonomik kriz dönemlerinde tarımın sektörünün tekrar tercih edilebilen bir sektör haline geldiğini göstermesi bakımından ilginçtir. Ancak tarımsal istihdamdaki azalma eğiliminin nedenleri ÇSGB Uis (2017) belgesinde şu şekilde sayılmaktadır: makineleşmenin neden olduğu işgücü talebindeki azalma, miras yoluyla arazilerin bölünmesine ve üretim maliyetlerinin sürekli yükselmesine bağlı kırsal bölgelerde geçim olanaklarının daralması ve bütün bunlarla ilişkili olarak şehirlere zorunlu göçler. Tarım sektörünün giderek çözülmesi ve buna bağı oluşan göçle, bütün işgücü piyasası da yeniden şekillenmiştir. Buna göre, kırdaki eğitim ve vasıf düzeyi düşük işgücünün kentlere göçüyle birlikte, özellikle kadınların işgücüne katılımı, istihdamı ve ücretleri düşerken, kadın işsizliği de önemli ölçüde artış göstermiştir (Işın vd., 2010:20). 
FAO'nun raporuna (2012) göre, bütün çocuk işçilerin \%60'ı (129 milyon kız ve erkek) tarımda çalışmakta ve bunların $3 / 2$ 'sini ücretsiz aile çalışanı çocuklar oluşturmaktadır. Tarım sektöründe hem ücretsiz çocuk işçiliği, hem de genellikle 5-7 yaş arası çocuklardan oluşan işgücüne katılma oranları oldukça yüksektir. Tarımda çocuk işçiliği oranlarının yüksek olmasının en temel nedeni ise, yoksulluktur. Türkiye'de de tarımsal istihdamla ilgili yaşanan en önemli sorunlardan biri, şüphesiz tarımda ücretsiz aile işçisi olarak çalıştırılan 15 yaş altı çocuklardır. Türkiye'de çalışan çocukların yaklaşık \%40-50'si daha çok çapa ve hasat gibi tarım işlerinde çalıştırılmaktadır. Genellikle, Güneydoğu ve Doğu Anadolu Bölgeleri'nde yılın 4-7 ayını göçebe ve temel ihtiyaçlarından mahrum olarak çadırlarda yaşamak zorunda kalan bu çocuklar, çalışmadan dolayı ya temel eğitimlerine devam edememekte, ya da eğitimden tamamen yoksun bırakılmaktadır (Gülçubuk, 2012:77). Diğer taraftan, çocuk işçiliğinin çocuğun gelecek yaşamıyla ilgili birçok olumsuzluğu içinde barındırmasına rağmen, aile çiftçiliği bağlamında çocukların üretken faaliyetlere katılımının tamamı çocuk işçiliği olarak kabul edilmez. Örneğin, çocuğun zorunlu eğitimine müdahale etmeyen, tehlikeli olmayan ve yaşa uygun görevler, hane halkı gıda güvenliğine önemli katkılar sağlamanın yanı sıra, çocuklara gelecekleri için tarımsal ve diğer beceriler kazandırabilmektedir (FAO, 2012:19). Bütün bu tartışmalar, bir tarafta yoksulluk nedeniyle özellikle tarım sektöründe çocuk emeğinin kötüye kullanılması, diğer tarafta ise, çocukların gelecek yaşamlarına hazırlanması bağlamında, çocuk işçiliğinin paradoksal yönünü ortaya koyması bakımından ilginçtir. Bu açıdan gelecek çalışmalarda bu konunun ayrıca ele alınması daha anlamlıdır.

\section{Araştırmanın Yöntemi}

\subsection{Veri ve Analiz Tekniği}

Bu araştırmada, TÜiK'in düzenli olarak yaptığı ve işgücü piyasasıyla ilgili arz yönlü veri toplayan 2016 yılına ait HiA mikro veri seti kullanıımıştır (TÜiK, 2018b). 380.709 katılımcının yer aldığı 2016 Hi̇'dan, bu çalışmanın bağımlı değişkenini incelemek için istihdam edilen 54.438 kadın içinden tarım sektöründe istihdam edilen 21.093 kadın ve istihdam edilen 116.964 erkek içinden tarım sektöründe istihdam edilen 25.222 erkekten oluşan bir örneklem grubu oluşturulmuştur.

Bu çalışmanın metodu esas olarak, 2016 HiA mikro veri setinin non-parametrik testlerden iki kategorik rassal değişken arasındaki ilişkiyi açıklamak ve bu değişkenlerin birbirinden bağımsız olup olmadığını test etmek için yaygın olarak kullanılan (Karagöz, 2010:28) Ki kare bağımsızlık testi ile analiz edilmesine dayanmaktadır. Ki kare bağımsızlık testinin uygulanabilmesi için gözlemlenen durumların frekanslarını gösteren kontenjans tabloları (çapraz tablo) kullanılmaktadır. Kontenjans tabloları, değişken sınıflarının bulunduğu satır sayısı " $r$ " ve sütun sayısı da "c" ile sembolize edilirse, $r$ Xc biçiminde elde edilir. Bu tip sınıflandırmalar satırdaki herhangi bir kategori ile sütundaki herhangi bir kategori arasındaki bağımlılık ya da bağımsızlık ilişkisini incelemektedir. Tablolardaki sıfır hipotezi $\left(\mathrm{H}_{0}\right)$ "Bu iki olay birbirinden bağımsızdır, birbirlerini etkilememektedir", alternatif hipotez $\left(\mathrm{H}_{\mathrm{A}}\right)$ ise, "Olaylar birbirinden bağımsız değildir, birbirleri arasındaki ilişki anlamlıdır" biçimindedir. Bunu tespit etmek için her satır veya sütundaki kategorilere ait beklenen frekans ile gözlenen frekans arasında bir karşılaştırma yapılmaktadır (Demirgil, 2014:90; Karagöz, 2010:28). 


\subsection{Değişkenler}

Araştırmanın bağımlı değişkeni tarım sektöründe istihdam edilme durumudur. Katılımcıların tarım sektöründe istihdam durumlarını tespit etmek için HíA soru kâğıdında istihdam edilenleri esas çalıştıkları kuruluş veya işyerinin Avrupa Topluluğunda Ekonomik Faaliyetlerin İstatistiki Sınıflaması'na (NACE2) göre ayıran NACE2_ESAS_K kodlu değişkenden faydalanılmıştır. Buna göre, NACE2'deki 1 kodlu "bitkisel ve hayvansal üretim ile avcılık ve ilgili hizmet faaliyetlerinde", 2 kodlu "ormancllık ile endüstriyel ve yakacak odun üretiminde" ve 3 kodlu "balıkçılık ve su ürünleri yetiştiriciliğinde" çalışanlar "tarım sektöründe çalışanlar" olarak yeniden kodlanırken, geri kalan sektörler de "tarım dışı sektörlerde çalışanlar" olarak yeniden kodlanarak, iki yönlü (dichotomous) yeni bir değişken elde edilmiştir.

Çalışmanın bağımsız değişkenleri katılımcıların sorulara verdiği cevaplardan alınmış olup, daha anlamlı sonuçlar elde etmek için bazı kategoriler birleştirilerek ya da çıkarılarak kullanılmıştır. Buna göre, bu çalışmada kullanılan bağımsız değişkenler; yaş, bitirilen okul, işteki durum, işyeri ölçeği, esnek çalışma, SGK kaydı, zamana dayalı eksik istihdam ve ikamet edilen bölgeden oluşmaktadır.

Tarım sektöründeki istihdam ve yaş kategorileri arasındaki ilişki, çalışma çağı nüfusu ve örneklemin cinsiyet dağılımı dikkate alınarak, 15-24, 25-34, 35-49 ve 50-64'den oluşan dört grupta incelenmiştir. Bir diğer bağımsız değişken, bitirilen okul, katılımcıların bitirdiği en son eğitim durumunu belirten "üniversite ve üstü", eğitimden "okul bitirmeyene" yukarıdan aşağı 5 kategoride sıralanmıştır. İşteki durum değişkeni ücretli, "maaşlı veya yevmiyeli", "işveren", "kendi hesabına çalışan" ve "ücretsiz aile işçisi" olmak üzere dört kategoride ele alınmıştır. İşyeri ölçeği değişkeni işyerinde çalışan sayısını esas almakta olup, 10 ve daha az işçi çalıştıran işyerleri "mikro ölçekli", 11-49 arası iş̧̧i çalıştıran işyerleri "küçük ölçekli" ve 50 ve üstü işçi çalıştıran işyerleri ise, "orta ve büyük ölçekli" olarak yeniden kodlanmıştır. Esnek çalışma değişkeni içinde yer alan işlerin "yarı zamanlı ya da tam zamanlı" ve "sürekli ya da geçici veya sınırlı süreli" olması ve istihdam edilenlerin "kayıt dışı" ya da "kayıtlı" olarak çalıştırılması katılımcıların kendi cevaplarından alınmıştır. Esas işinde ve diğer işinde/işlerinde toplam olarak 40 saatten daha az süre çalışmış olup, daha fazla süre çalışmak istediğini belirten çalışanlardan oluşan zamana dayalı eksik istihdam değişkeni ise, tarım sektörü ve tarım dışı sektörler olarak iki kategori içinde değerlendirilmiştir. Son bağımsız değişken ise, ikamet edilen bölgeler için, 1 . düzey İstatistiki Bölge Birimleri Sınıflamasına göre (TR1'den TRC'ye), 12'li sınıflandırmadan faydalanılmıştır.

\subsection{Araştırmanın Bulguları ve Sonuçları}

Bu bölümde tarımsal istihdam ile bağımsız değişkenler arasındaki ilişkinin cinsiyete göre farklılaşan oranları ve bu farklılıkların birbirinden bağımsız olup olmadığını test eden Ki kare bağımsızlık test sonuçları gösterilmiştir. Daha sonra elde edilen bulgulara göre sonuçlar analiz edilerek, bu sonuçlara ilişkin değerlendirmeler yapılmıştır. 
Tablo 1: Tarımsal istihdam ve yaş grupları ilişkisi

\begin{tabular}{llcrc}
\hline & KADIN & \multicolumn{2}{c}{ ERKEK } \\
\hline \hline $15-24$ & $\mathrm{~N}^{\mathrm{a}, \mathrm{b}}$ & $\%^{\mathrm{c}}$ & $\mathrm{N}^{\mathrm{a}, \mathrm{b}}$ & $\%^{\mathrm{c}}$ \\
$25-34$ & 2.487 & 32,3 & 6.058 & $19,3^{* * *}$ \\
$35-49$ & 2.777 & 21,9 & 5.086 & $9,3^{* * *}$ \\
$50-64$ & 7.231 & 33,6 & 12.788 & $14,4^{* * *}$ \\
\hline
\end{tabular}

Kaynak: Yazarın 2016 Hanehalkı İşgücü Anketinden kendi analizi

a Örneklem büyüklüğü ağırlıklıdır.

b Her bir kategoride bulunanların \% dağılımları

c Ki kare sonuçları her bir satırda erkek ve kadın için ${ }^{*} \mathrm{p}<, 05 ;{ }^{* *} \mathrm{p}<, 01 ;{ }^{* *} \mathrm{p}<, 001$

Tablo 1'deki tarımsal istihdam ve yaş grupları ilişkisi incelendiğinde, cinsiyetler arasında anlamlı farklılıklar olduğu göze çarpmaktadır $(p<, 001)$. Ayrıca bütün yaş bantları içinde tarımdaki kadın istihdamının, erkelere göre, daha yüksek oranlarda olduğu gözlemlenmektedir. Tabloda dikkat çeken bir diğer ayrıntıda, genç yaşlardan ileri yaşlara gidildikçe kadın ve erkek arasındaki istihdam açıklığının giderek arttığı ve tarımsal istihdam ile yaş grupları arasında bir " $U$ " ilişkisinin olduğudur. Buna göre, her iki cinsiyette de çoğunluğu ücretsiz aile çalışanlarından oluşan 15-24 yaş grubundaki yüksek tarımsal istihdam, 25-34 yaş bandında büyük ihtimalle kırdan kente göçle birlikte bir azalma gösterirken, 35-49 yaş bandından itibaren yeniden yükselişe geçmektedir. Ancak, tarımsal istihdam ve yaş bantları ilişkisinde cinsiyetler arasındaki en dikkat çekici açıklık, 50-64 yaş bandında oluşmuştur. Buna göre, 50-64 yaş bandındaki kadınların (\%66) tarımda istihdam edilmeleri, erkeklere $(\% 38,4)$ göre, anlamlı şekilde daha yüksektir. Özellikle emekli olduktan sonra kırsal kesime yerleşerek tarımsal faaliyetler içine girenler, 50-64 yaş bandında tarımsal istihdamı önemli ölçüde artırmaktadır.

Tablo 2: Tarımsal istihdam ve eğitim ilişkisi

\begin{tabular}{|c|c|c|c|c|}
\hline & \multicolumn{2}{|c|}{ KADIN } & \multicolumn{2}{|c|}{ ERKEK } \\
\hline & $\mathrm{N}^{\mathrm{a}, \mathrm{b}}$ & $\%^{\mathrm{c}}$ & $\mathrm{N}^{\mathrm{a}, \mathrm{b}}$ & $\%^{c}$ \\
\hline Üniversite ve üstü & 214 & 1,7 & 1.542 & $3,6 * * *$ \\
\hline Mesleki ve teknik lise & 341 & 9,4 & 2.514 & 9,5 \\
\hline Genel lise & 444 & 11,6 & 2.382 & $10,2^{* *}$ \\
\hline Lise altı eğitim & 12.914 & 51,1 & 38.800 & $29,6 * * *$ \\
\hline Okul bitirmeyen & 7.180 & 76,9 & 5.286 & $50,6 * * *$ \\
\hline
\end{tabular}

Kaynak ve notlar için Tablo 1'e bakınız.

Tablo 2'de tarımsal istihdam ve bitirilmiş eğitim kategorileri ilişkisinde cinsiyetler arasında anlamlı farklılıkların olduğu görülmektedir $(p<, 001)$. Tabloda dikkat çeken nokta, bitirilen eğitimle tarımsal istihdam arasında ters orantılı bir ilişkinin bulunmasıdır. Yani, her iki cinsiyet açısından eğitim düzeyi düştükçe, tarımda istihdam edilme olasılığı da lineer bir modda artmaktadır. Ayrıca, sadece üniversite ve üstü eğitim düzeyine sahip erkeklerin \%3,6'sının tarımda istihdam edilmesi, kadınlara $(\% 1,7)$ oranla, anlamlı şekilde daha yüksekken, kazanılmış eğitim derecesi düştükçe, kadınların tarımdaki istihdam oranlarının, erkeklere kıyasla, giderek yükseldiği görülmektedir. Üniversite ve üstü eğitim düzeyinde tarımdaki erkek istihdam oranının daha yüksek olmasında, ziraat mühendisliği ve veterinerlik gibi vasıflı mesleklerin erkekler tarafından daha çok tercih edilmesinin bir etkisi olabilir. Ancak, tarımsal istihdam ve bitirilmiş eğitim kategorileri ilişkisinde cinsiyetler arasındaki en çarpıcı açıklık kadınlar lehine "hiç bir 
okul bitirmeyenler" arasında oluşmuştur. Buna göre, okul bitirmeyen kadınların \%76,9'unun tarım sektöründe istihdam edilmeleri, erkeklere kıyasla $(\% 50,6)$, anlamlı şekilde daha yüksek görünmektedir. Bu durum, kırsal kesimde yaşayanların, özellikle de kadınların, eğitime katılım oranlarının hala düşük kalması ile açıklanabilir.

Tablo 3: Tarımsal istihdam ve işteki durum ilişkisi

\begin{tabular}{lrrrr}
\hline & \multicolumn{1}{c}{ KADIN } & \multicolumn{2}{c}{ ERKEK } \\
\hline \hline Ücretli, maaşlı veya yevmiyeli & $\mathrm{N}^{\mathrm{a}, \mathrm{b}}$ & \% $^{\mathrm{c}}$ & $\mathrm{N}^{\mathrm{a}, \mathrm{b}}$ & $\%^{\mathrm{c}}$ \\
İşveren & 1.266 & 4,3 & 4.644 & $3,1^{* * *}$ \\
Kendi hesabına çalışan & 25 & 4,1 & 758 & 5,8 \\
Ücretsiz aile işçisi & 2.170 & 41,9 & 36.096 & $61,1^{* * *}$ \\
\hline
\end{tabular}

Kaynak ve notlar için Tablo 1'e bakınız.

Tablo 3'de tarımsal istihdam ve işteki durum ilişkisinde cinsiyetler arasında anlamlı farklılıkların olduğu izlenmektedir ( $p<, 001)$. Tablodan, tarımda ücretli, maaşlı veya yevmiyeli çalışan ve işveren oranlarının oldukça düşük, kendi hesabına çalışan ve ücretsiz aile işçiliğinin ise, çok yüksek olduğu anlaşılmaktadır. Cinsiyetler arasındaki en kayda değer açıklık kendi hesabına çalışan ve ücretsiz aile işçiliğinde görülmektedir. Buna göre, kendi hesabına çalışan erkeklerin \%61,1'inin tarım sektöründe yer alması, kadınlara (\%41,9) kıyasla, anlamlı bir şekilde daha yüksekken, ücretsiz aile işçisi kadınların \%91,5'inin tarımda çalışması, erkeklere (\%73) nazaran, kayda değer bir şekilde daha yüksek beklenmektedir. Bu sonuçlar, tarım sektörünün genellikle küçük aile çiftçiliğinden daha ileri gidememesinin bir sonucu olarak, işgücü talebinin genellikle aile içinden veya imece usulü ile ücretsiz bir şekilde karşılanmasının çok yaygın olduğunu, diğer taraftan geçici ya da daimi ücretli işgücü kullanımının çok daha sınırlı kaldığını göstermektedir. Genel olarak, tarımsal işlerin görülmesinde esas unsur ücretsiz aile bireyleri iken, ücretli işgücü gerek duyulursa devreye giren ikincil bir unsur olarak görülmektedir. Ancak, tarımsal işyerlerinin ölçeği büyüdükçe, ücretli işgücü esas unsur haline gelmektedir (Yıldırak vd., 2002'den akt. Işın vd., 2010:10).

Tablo 4: Tarımsal istihdam ve işyeri ölçeği ilişkisi

\begin{tabular}{lrrrr}
\hline & KADIN & \multicolumn{2}{c}{ ERKEK } \\
\hline \hline 1-10 mikro ölçek & $\mathrm{N}^{\mathrm{a}, \mathrm{b}}$ & \% $^{\mathrm{c}}$ & \multicolumn{1}{c}{$\mathrm{N}^{\mathrm{a}, \mathrm{b}}$} & $\%^{\mathrm{c}}$ \\
11-49 küçük ölçek & 20.574 & 58 & 48.938 & $35,7^{* * *}$ \\
50 ve üstü orta ve büyük ölçek & 394 & 4,6 & 1.040 & $2,6^{* * *}$ \\
\hline
\end{tabular}

Kaynak ve notlar için Tablo 1'e bakınız.

Tablo 4'te tarım sektöründe istihdam ve işyeri ölçeği ilişkisinde kayda değer cinsiyet farklıIıklarının olduğu gözlenmektedir $(p<, 001)$. Cinsiyetler arasındaki en önemli açıklık mikro ölçekli işyerlerinde ortaya çıkmıştır. Buna göre, mikro ölçekli işyerlerinde çalışan kadınların $\% 58$ 'inin tarım sektöründe yer alması erkeklere $(\% 35,7)$ göre anlamlı şekilde daha yüksektir. Ayrıca işyeri ölçeği büyüdükçe, istihdam oranları da ters orantılı bir şekilde düşmektedir. Bu oranlar Türkiye'deki tarımsal faaliyetlerin hala geçimlik tarım faaliyetleri aşamasında olduğunu ve tarım sektöründeki kurumsallaşma sorununu teyit etmektedir. Ayrıca "geçimlik tarım"dan "piyasa tarımı"na geçiş süreci üretim ve işgücü planlamasından, ürünlerin değerlemesi ve pazarlanmasına kadar birçok karmaşık değişimi zorunlu kıldığı için kurumsal destek almaksızın mikro ölçekli tarımsal işyerlerinin bu değişimleri gerçekleştirebilmesi bir hayli zor görünmek- 
tedir (Gülçubuk vd., 2005:1). Türkiye'de bu değişim süreci, gerçekleştirilemediği ölçüde, tarımsal istihdamda ücretsiz aile işçiliğinden ücretli işçiliğe geçiş sağlanamamaktadır.

Tablo 5: Tarımsal istihdam ve esnek çalışma biçimleri ilişkisi

\begin{tabular}{lcrrr}
\hline & KADIN & & ERKEK \\
\hline \hline Kısmi süreli & $\mathrm{N}^{\mathrm{a}, \mathrm{b}}$ & $\%^{\mathrm{c}}$ & $\mathrm{N}^{\mathrm{a}, \mathrm{b}}$ & $\%^{\mathrm{c}}$ \\
Tam süreli & 7.795 & 62,2 & 10.224 & $56,2^{* * *}$ \\
Sürekli iş & 13.298 & 31,7 & 40.220 & $18,6^{* * *}$ \\
Geçici veya sınırlı süreli iş & 204 & 0,8 & 1.624 & $1,3^{* * *}$ \\
\hline
\end{tabular}

Kaynak ve notlar için Tablo 1'e bakınız.

Tablo 5'te tarımda istihdam ile esnek çalışma biçimleri ilişkisinde cinsiyetler arasında anlamlı farklılıkların olduğu görülmektedir $(p<, 001)$. Tabloya bakıldığında, kısmi süreli çalışan kadınların \%62,2'sinin tarım sektöründe çalışması, erkeklere $(\% 56,2)$ kıyasla, anlamlı şekilde daha yüksektir. Benzer şekilde, geçici veya sınırlı süreli işlerde istihdam edilen kadınların $\% 26,3^{\prime}$ ünün tarım sektöründe istihdam edilmesi de, erkeklere $(\% 12,9)$ göre, anlamlı şekilde daha yüksek görülmektedir. Bu sonuçlar, hayvancılıkla ilgili faaliyetler yıl boyunca devam ettiğinden, hayvancllıktaki işgücü talebi önemli ölçüde değişmezken, bitkisel üretimin, kendine has özelliği gereği, işgücü talebi yıl içerisinde önemli ölçüde değişkenlik göstermektedir. Bu anlamda ürün desenine bağlı olarak, Haziran, Temmuz ve Ağustos aylarında işgücü talebi artarken, Ocak ve Şubat aylarında en düşük seviyeye inmektedir. Diğer taraftan kullanılan teknolojiye, bölgesel ve iklime bağlı farklııklar da işgücü talebinde farklılaşmalara neden olmaktadır (Işın vd., 2010:7).

Tablo 6: Tarımsal istihdam ve SGK kaydı ilişkisi

\begin{tabular}{lcrrr}
\hline & KADIN & \multicolumn{3}{c}{ ERKEK } \\
\hline \hline Kayıt dışı & $\mathrm{N}^{\mathrm{a}, \mathrm{b}}$ & $\%^{\mathrm{c}}$ & $\mathrm{N}^{\mathrm{a}, \mathrm{b}}$ & $\%^{\mathrm{c}}$ \\
Kayıtlı & 19.984 & 69,2 & 37.296 & $48,2^{* * *}$ \\
\hline Kaynak & 1.109 & 4,3 & 13.148 & $8,4^{* * *}$ \\
\hline
\end{tabular}

Kaynak ve notlar için Tablo 1'e bakınız.

Tablo 6 tarımsal istihdam ile kayıt dışı çalışma arasında cinsiyete göre önemli farklılıkların olduğunu göstermektedir ( $p<, 001$ ). Buna göre, kayıt dışı çalışan kadınların \%69,2'sinin tarımsal istihdam içinde yer alması, erkeklere $(\% 48,2)$ oranla anlamlı şekilde daha yüksektir. Bu sonuç, tarım sektöründeki ücretsiz aile işçiliğinin çok yaygın olmasının bir yansımasıdır. Ayrıca, tarım sektörünün yılın belli dönemlerinde yoğunlaşan, diğer dönemlerinde tamamen ya da kısmen duran işleri kapsayan mevsimsellik özelliği, bu sektörde hayvancılık dışında daimi ve sürekli çalışmaktan ziyade, geçici ve süreksiz çalışmayı özendirmektedir.

Daha önce özel olarak 2926 sayılı Kanun ile düzenlenen tarım kesiminde çalışanların sosyal güvenliği, 2008 yılından itibaren 5510 sayılı Kanun kapsamına alınmıştır. Daha sonra, 2011 yılında 6111 sayılı Kanun ile 5510 sayılı Kanun'a Ek Madde 5 ile "Tarım veya orman işlerinde hizmet akdiyle süreksiz olarak çalışanların sigortalıı̆̆ı” eklenmiştir. Bu düzenlemeyle tarımda süreksiz olarak çalışanlar kendi "isteklerine" bağlı olarak, analık sigortası hariç olmak üzere, prime esas kazancın \%34,5'i oranında 21 günlük prim ödeyerek, 30 günlük hizmet hakkı kazanmıştır (bkz. Demir, 2015). Ancak, elde edilen bu oranlar, 2011 yılında 6111 sayılı Kanun ile 5510 sayılı kanuna Ek Madde 5’le getirilen düzenlemelerin istenen sonuçları doğurmadığını 
açıkça göstermektedir. Ayrıca kırsal kesimde çok daha yoğun yaşanan yoksulluk ve gelir düşüklüğüne bir de sosyal güvence yoksunluğunun eklenmesi, bu sorunları iyice kötüleştirmektedir (Işın vd., 2010:11).

Tablo 7: Sektörler ve zamana dayalı eksik istihdam ilişkisi

\begin{tabular}{lcrrr}
\hline & KADIN & \multicolumn{3}{c}{ ERKEK } \\
\hline \hline $\mathrm{N}^{\mathrm{a}, \mathrm{b}}$ & $\%^{\mathrm{c}}$ & \multicolumn{2}{c}{$\mathrm{N}^{\mathrm{a}, \mathrm{b}}$} & \multicolumn{1}{c}{$\%^{\mathrm{c}}$} \\
\hline \hline Tarım sektörü & 317 & 2,2 & 1.482 & $6,3^{* * *}$ \\
Tarım dışı sektörler & 555 & 7 & 2.306 & $11,7^{* * *}$ \\
\hline
\end{tabular}

Kaynak ve notlar için Tablo 1'e bakınız.

Tablo 7 tarım sektörü ve tarım dışı sektörler ile zamana dayalı eksik istihdam ilişkisinde cinsiyetler arasında anlamlı farklılıklar olduğunu ortaya koymaktadır $(p<, 001)$. Tablodan öncelikle tarım sektöründeki her iki cinsiyetin zamana dayalı eksik istihdam oranın, tarım dışı sektörlere göre, daha düşük olduğu izlenmektedir. Bu durum, tarım sektöründe 40 saatten daha az süreli çalışanların daha fazla sürelerde çalışma isteklerinin tarım dışı sektörlerden anlamlı şekilde düşük olduğunu göstermektedir. Diğer taraftan, tarım sektöründe zamana dayalı eksik istihdam edilen kadınların $(\% 2,2)$, benzer şekilde istihdam edilen erkeklere $(\% 6,3)$ oranla, anlamlı şekilde düşük olduğu görülmektedir. Yani, tarım sektöründeki 40 saatten daha az süreli çalışan kadınlar arasında daha fazla sürelerde çalışma eğilimi erkeklerden daha düşüktür.

Tablo 8: Tarımsal istihdam ve ikamet edilen bölgeler ilişkisi

\begin{tabular}{lrrrr}
\hline & \multicolumn{3}{c}{ KADIN } & \multicolumn{2}{c}{ ERKEK } \\
\hline \hline TR1 istanbul & $\mathrm{N}^{\mathrm{a}, \mathrm{b}}$ & \% $^{\mathrm{c}}$ & \multicolumn{1}{c}{$\mathrm{N}^{\mathrm{a}, \mathrm{b}}$} & \multicolumn{1}{c}{ \% $^{\mathrm{c}}$} \\
TR2 Batı Marmara & 59 & 1,2 & 202 & 0,9 \\
TR3 Ege & 1.420 & 33,5 & 4.238 & $24,6^{* * *}$ \\
TR4 Doğu Marmara & 2.874 & 37,3 & 6.514 & $22,4^{* * *}$ \\
TR5 Batı Anadolu & 748 & 17,9 & 2.178 & $11,3^{* * *}$ \\
TR6 Akdeniz & 1.261 & 22,3 & 3.764 & $13,7^{* * *}$ \\
TR7 Orta Anadolu & 1.960 & 33,1 & 5.522 & $21,3^{* * *}$ \\
TR8 Batı Karadeniz & 1.653 & 50,2 & 4.210 & $26,5^{* * *}$ \\
TR9 Doğu Karadeniz & 3.594 & 59,2 & 7.088 & $34^{* * *}$ \\
TRA Kuzeydoğu Anadolu & 2.432 & 67,8 & 4.076 & $37,4^{* * *}$ \\
TRB Ortadoğu Anadolu & 2.338 & 72,5 & 5.550 & $43,1^{* * *}$ \\
TRC Güneydoğu Anadolu & 1.767 & 58,7 & 3.758 & $26,4^{* * *}$ \\
\hline
\end{tabular}

Kaynak ve notlar için Tablo 1'e bakınız.

Son olarak, Tablo 8 Türkiye' de tarımsal istihdam ve ikamet edilen bölgeler arasındaki ilişkide, cinsiyetler açısından anlamlı farklılıkların olduğunu göstermektedir. Buna göre, ekonomik olarak en gelişmiş bölge olan İstanbul'da tarımsal istihdamın en düşük, diğerlerine göre daha az gelişmiş olan Doğu Karadeniz ve Kuzeydoğu Anadolu Bölgeleri'nde tarımsal istihdamın daha yüksek olduğu açıktır. Tarımsal istihdamdaki en çarpıcı cinsiyet açıklığı Doğu Karadeniz Bölgesi'nde ortaya çıkmıştır. Buna göre; Trabzon, Ordu, Giresun, Rize, Artvin ve Gümüşhane illerinin yer aldığı Doğu Karadeniz Bölgesi'nde yaşayan kadınların \%67,8'inin tarımda istihdam edilmesi, aynı illerde yaşayan erkeklere $(\% 37,4)$ kıyasla, anlamlı şekilde daha yüksektir. Diğer taraf- 
tan, hem kadın, hem de erkek açısından, tarımsal istihdamın en yüksek olduğu bölge ise; Erzurum, Erzincan, Bayburt, Ağrı, Kars, Iğdır ve Ardahan illerini içine alan Kuzeydoğu Anadolu Bölgesi'dir. Bu bölgede kadın istihdamın \%72,5'inin tarımsal istihdamda yer alması, erkeklere $(\% 43,1)$ kıyasla, anlamlı şekilde daha yüksektir. Bu oranlar, Karadeniz ve Doğu ve Güneydoğu illerinde tarım sektörünün sosyo-ekonomik açıdan hala en önemli bir geçim kaynağı olmaya devam ettiğini göstermektedir.

\section{Sonuç}

Bu çalışmada, tarımsal istihdam ile demografik ve istihdamla ilgili değişkenler arasındaki ilişkide, cinsiyet farklılıklarının anlamlı olup olmadığı, oluşturulan kontenjans tablolarına Ki kare bağımsızık testleri uygulanarak açıklanmaya çalışıımıştır. Elde edilen sonuçlar, dünyadaki genel trende uygun bir şekilde, Türkiye'de de tarımda kadın istihdam oranının, analizde kullanılan değişkenler arasında farklı derecelerde olmak üzere, erkeklerden daha yüksek olduğu yönündedir. Ancak, tarımda kadın istihdamının en temel itici gücü \%91,5 ile ücretsiz aile iş̧̧iliğidir, zira diğer ücretli ve yevmiyeli, kendi hesabına çalışan ve işveren oranları erkeklerde daha yüksek izlenmektedir (bkz. Tablo 3). Çalışmadan elde edilen diğer ampirik bulgular şu şekilde özetlenebilir:

$\checkmark \quad$ Tarımsal istihdam ile yaş grupları arasında genç yaş grubunda artan, 25-34 yaş grubunda düşen ve daha ileriki yaş gruplarında tekrar artan bir “ $U$ ” ilişkisi görülmüştür. Bu durum dinamik iş gücünün kırsal alandan göç etmesi, geride ya genç ya da yaşlı nüfusun kalmasının bir sonucudur.

$\checkmark \quad$ Tarımsal istihdam ile eğitim arasında, lise altı eğitimliler ve okul bitirmeyenlerin çok yüksek oranlarda olduğu, ters orantılı bir ilişki tespit edilmiştir. Bu durum, kırdan kente göç edenlerin istihdam olanaklarını önemli ölçüde düşürerek, kentlerde yapısal işsizliğin artmasına yol açmaktadır.

Tarımsal istihdamın önemli bir bölümü, aile bireylerinin esas, ücretli işgücünün ise, ikincil unsur olarak kullanıldığı, mikro ölçekli işyerlerinde yoğunlaştığı görülmüştür. Bu durum, Türkiye'de tarım sektörünün geçimlik tarımdan piyasa tarımına geçişini hala tamamlayamadığı gerçeğini ortaya koymaktadır.

Tarım sektörünün mevsimsellik özelliğine bağlı olarak, daha çok bitkisel üretimde kısmi zamanlı, geçici ve süreksiz a-tipik çalışma biçimlerin daha yaygın olduğu görülmektedir. A-tipik çalışma biçimlerinin ve ücretsiz aile işçiliğinin çok yaygın olmasının doğal bir sonucu olarak, tarım sektöründe sosyal güvence yoksunluğu da çok yüksek düzeydedir. Diğer taraftan tarım sektöründe zamana dayalı eksik istihdamın, tarım dışı sektörlere göre, daha düşük olduğu tespit edilmiştir.

$\checkmark \quad$ Tarımsal istihdam, gelişmiş bölgelerden ziyade, tarımın hala en önemli bir geçim kaynağı olmaya devam ettiği, görece daha az gelişmiş Karadeniz Bölgesi ile Doğu ve Güneydoğu bölgelerinde önemini korumaktadır. Bu sonuç, Türkiye'de bölgeler arası gelişmişlik farklılığı sorununun devam ettiğini açıkça göstermektedir.

Tarımsal istihdamla ilgili tespit edilen bulguların, Türkiye'nin geçmişten günümüze gelen yapısal sorunlarından kaynaklandığı söylenebilir. Dolayısıyla, uzun dönemli sorunların çözüme kavuşturulması veya azaltılması bir takım hukuki ve idari reformlarla desteklenen uzun vadeli 
bir program gerektirmektedir. Ayrıca, son bölümünde tarımsal istihdamla ilgili yapılan ampirik tespitler ışığında kısa ve uzun vadede şu sosyal politika önlemlerin alınması önem arz etmektedir:

1. Gençleri, özellikle yüksek eğitimlileri, tarım sektöründe çalışmaya özendirmek için gençlere yönelik çeşitli tarımsal girişimcilik eğitimleri düzenlenip, bu eğitimlerin sonunda, kira karşılığı atıl durumdaki arazilerde uzun vadeli kredi imkânlarıyla yeni tarımsal girişimlerin kurulmasına olanak sağlanmalıdır. Ayrıca, yeni kurulacak bu tarımsal girişimlere insan kaynakları, üretim, pazarlama ve finansman yönünden ücretsiz danışmanlık desteği verilmelidir. Böylece, bir taraftan genç işsizliği azaltılırken, diğer taraftan, atıl tarımsal alanlar işlenerek, tarımsal üretimde bir artış sağlanabilir. Ayrıca orta ve uzun vadede geriye göçün ve Türkiye'nin tarımda daha iyi bir noktaya gelmesinin de önü açılabilir.

2. Kır-kent arasındaki eğitime ulaşılabilirlik dengesizliklerin giderilmesine yönelik çabaların artırılması ve ailelerin çocuklarının, özellikle kız çocuklarının, eğitimi konusundaki bilinç eksikliğini artıracak çalışmaların yaygınlaştırılmasıyla, bilhassa kırsal kesimde yaşayan eğitimli birey oranı yükseltilebilir.

3. Türkiye'deki tarımsal işyerleri daha çok aile işletmesi niteliğinde olup, dağınık bir yapıda, pazarlama ve eğitim yönünden eksik, teknoloji kullanımının ve kooperatif örgütlenmesinin yetersiz olduğu bir yapıdadır (Yıldız vd., 2017:21). Bu yapı içerisindeki tarım işletmelerinin, geçimlik tarımdan piyasa tarımına geçişini kolaylaştırmak için, üretim, insan kaynakları, finansman, ürün değerlemesi ve pazarlaması açısından desteklenmesiyle, işyeri ölçeklerinin büyümesi sağlanabilir. Böylece, bir taraftan tarımsal istihdamda ücretsiz aile işçiliği oranı azaltılırken, diğer taraftan, ücretli, kendi hesabına çalışan ve işveren oranları artırılabilir.

4. Tarımsal istihdamın mikro ölçekli işyerlerinde yoğunlaşması, ücretsiz aile işçiliğinin ve kısmi süreli, geçici veya sınırlı süreli istihdam biçimlerinin çok yaygın olması tarımsal istihdamda kayıt dışı çalışmayı artıran temel faktörlerdir. Ayrıca, kadınlar hem bu istihdam biçimlerinden, hem de kayıt dışı istihdamdan erkeklerden çok daha fazla etkilenmektedir. Tarımda kayıt dışılığı azaltmak için öncelikle geçimlik tarımdan piyasa tarımına geçişi sağlamaya yönelik önlemlerin alınması ve bu şekilde tarımsal işyerlerinin ölçek ve kapasitelerinin artmasıyla, hem ücretsiz aile işçiliğinin, hem de a-tipik güvencesiz istihdam biçimlerinin azaltılması sağlanabilir.

5. Tarımsal istihdamdaki yüksek kayıt dışılığı düşürmek için öncelikle tarım sektörünün kendine özgü mevsimsellik ve daha yaygın olan yoksulluk, ücretsiz aile işçiliği ve a-tipik istihdam özelliklerinin göz önünde bulundurması gerekmektedir. Bu çerçevede, 5510 sayılı Kanun'da yapılacak değişiklikle, tarımsal faaliyet içinde bulunan $4 a$ hizmet akdi ile ve $4 \mathrm{~b}$ kendi adına ve hesabına bağımsız çalışanlardan, belli bir gelirin altında (örneğin aylık asgari ücret) aylık kazancı olanların sigorta primlerinin tamamının devlet tarafından karşılanması, gerek sosyal politika, gerekse Anayasa'nın 2. maddesindeki sosyal devlet ilkesine daha uygun bir çözüm olabilir. Böylece, hem kırsalda tarımsal faaliyetlerde çalışan yoksulların önemli bir kısmı sosyal güvence altına alınmış olacak, hem de diğer önemlerle beraber tarımsal girişimcilik için önemli bir teşvik sağlanmış olacaktır.

6. Son olarak, tarım çalışanlarının gerek açık, gerekse kapalı alanlarda oldukça zor koşullarda çalışmalarına rağmen, elde ettikleri gelir hem yetersiz, hem de süreksizdir. Ayrıca tarım çalışanlarının işe başlama, bitirme ve dinlenme süreleri tarımsal faaliyetlerin özelliklerine göre, önemli ölçüde değişiklik göstermektedir (Işın vd., 2010:20). Ancak, tüm tarım ça- 
Iışanlarının \%98'ini oluşturan 50'nin altında işçi çalıştıran işyerlerinde çalışmakta olan tarım işçileri, 4857 sayılı İş Kanunu'nun 4/b maddesindeki istisna nedeniyle, İş Kanunu'nun koruyucu hükümlerinden faydalanamadıkları için bu gruptaki tarım çalışanlarının tamamına 6098 sayılı Borçlar Kanunu hükümleri uygulanmaktadır. Bu nedenle, 4857 sayılı İ̧̧ Kanunu'nun 4/b maddesindeki 50 işçi sınırının makul olan daha aşağı bir düzeye çekilerek, 4857 sayılı Kanun'un tarım çalışanları üzerindeki kapsayıcılığının artırılması ve gerekirse tarım sektörünün kendine özgü koşullarını dikkate alan başka özel hükümler eklenmesi, tarım çaış̧anlarının çalışma koşullarını iyileşmesine katkı sağlayabilir. 


\section{Eskişehir Osmangazi Üniversitesi IïB Dergisi}

\section{Kaynaklar}

Alkan, Yaşar (2015), "Türkiye'de Tarımsal İşletmelerde Ücret İle İşgücüne Katılma İlişkisinin Ekonometrik Analizi”, Ardahan Üniversitesi Iktisadi ve Idari Bilimler Fakültesi Dergisi, 1 (2): 155-171.

Cinemre, Hüseyin Avni ve Kılıç, Osman (2011), Tarım Ekonomisi, 19 Mayıs Üniversitesi Yayınları, Samsun.

Çalışma ve Sosyal Güvenlik Bakanlığı (2017), Ulusal Istihdam Stratejisi, Tarım Sektörü, Ankara.

Daly, Patricia A. (1981), “Agricultural Employment: Has the Decline Ended?”, Montly Labor Review, 104: 11-17.

Demir, Müslim (2015), "Mevsimlik Tarım İşçilerinin Sosyal Güvenlik Haklarına İlişkin Değerlendirme/Öneriler”, Çalışma ve Toplum Dergisi, 2015/1: 177-194.

Demirgil, Hakan (2014), "Parametrik Olmayan (Non-Parametrik) Hipotez Testleri”, SPSS Uygulamalı Çok Değişkenli Istatistik Teknikleri, Ed. Kalaycı Ş., 6. Baskı, Ankara, Asil Yayın Dağıtım.

Diao, Xinshen; Hazell, Peter and Thurlow, James (2010), "The Role of Agriculture in African Development", World Development, Vol. 38, No. 10: 1375-1383 doi:10.1016/j.worlddev.2009.06.011.

Doğan, Zeki; Arslan, Seçkin ve Berkman, Ayberk Nuri (2015), “Türkiye'de Tarım Sektörünün İktisadi Gelişimi ve Sorunları: Tarihsel Bir Bakış", Niğde Üniversitesi Iktisadi ve Idari Bilimler Fakültesi Dergisi, Cilt-Sayı: 8 (1): 29-41.

Erkuş, Ahmet; Bülbül, Mehmet; Kıral, Taner; Açıl, Fethi ve Demirci, Rasih (2005), Tarım Ekonomisi, Ankara Üniversitesi Araştırma ve Geliştirme Vakfı Yayınları, Ankara.

Gülçubuk, Bülent; Şengül, Haydar; Aluftekin, Nilay; Kızılaslan, Nuray ve Kılıç, Mehmet (2005), "Tarımda İstihdam Sosyal Güvenlik Uygulamaları ve Kırsal Yoksulluk". TMMOB Ziraat Mühendisleri Odası VI. Teknik Kongresi, 3-7 Ocak 2005, S: 1173.

Gülçubuk, Bülent (2012), "Tarımda Çocuk Emeği Sömürüsü ve Toplumsal Duyarlılık”, Çalışma ve Toplum Dergisi, 2012/2: 75-93.

Food and Agriculture Organization of the United Nations (FAO) (2012), Statistical Yearbook 2012.

Fechter, Jürgen (2012), "Agriculture and employment", KFW Position Paper.

Işın, Ferruh; Keskin, Gülşen; Kılıç, Mehmet; Türkekul, Berna ve Ateş, Hacer Çelik (2010), "Türkiye'de Tarımsal İşgücü Piyasası ve Sosyal Güvenlik Politikaları", Ziraat Mühendisleri Odası VII. Teknik Kongre, Ankara: 1-22.

Karacan, Ali Rıza (1991), Tarım Kesiminde Geçici Tarım Iş̧ilerinin Çalışma Koşulları, Ücret Sistemleri ve Çalışanların Sosyal Güvenlikleri Üzerine Bir Araştırma: Manisa Örneği, Friedrich Vakfı, İstanbul (http://www.festuerkei.org/media/pdf/einzelpublikationen/Buch \%20Ali\%20Riza\%20Karacan.pdf Erişim 18.07.2018).

Karagöz, Yalçın (2010), "Non-parametrik Tekniklerin Güç ve Etkinlikleri”, Elektronik Sosyal Bilimler Dergisi, Cilt:9, Sayı:33: 18-40.

Kıral, Taner ve Akder, Halis (2000), “Makro Ekonomik Göstergelerle Tarım Sektörü”, Türkiye Ziraat Mühendisliği V. Teknik Kongresi, (2 cilt), Yayın No.38, Ankara: 1-19.

Makal, Ahmet (2001), "Türkiye'de 1950-1965 Döneminde Tarım Kesiminde İşgücü ve Ücretli Emeğe İlişkin Gelişmeler", Ankara Üniversitesi SBF Dergisi, Cilt: 56, Sayı: 3: 103-140.

Sapancalı, Faruk (2007), "Türkiye'de İşgücü Piyasası, Sorunlar ve Politikalar", TüHis iş̧ Hukuku ve iktisat Dergisi, Cilt: 21 Sayı: 2-3: 8-30.

Schwarcz, Pavol; Mura, Ladislav; Pätoprstý, Mário and Schwarczová, Loreta (2012), "The Impact of Employment in Agriculture on Overall Employment and Development: A Case Study of the District of Topol'čany, Slovakia", SEER: Journal for Labour and Social Affairs in Eastern Europe, Vol. 15, No. 4, Labour Markets and Trade Unions: 483-492.

Sındır, Kamil Okyay (2008), "Kırsal Yoksulluk ve Tarımda İstihdam", (http://www.zmo.org.tr/resimler/ekler/4351b79d9ea3d84_ek.pdf?tipi=38\&turu=D\&sube=0 Erişim 18.07.2018).

Tan, Sibel; Atak, Şermin; Şengül, Ümran and Tan, Sabri Sami (2015) "The Evaluation of the Changes in the Agricultural Sector with Common Economic Indicators in Turkey During the Last Decade", Mediterranean Journal of Social Sciences, Vol.6, No.2: 588-595, Doi:10.5901/mjss.2015.v6n2s1p588.

Türkiye İstatistik Kurumu (2018a), Hanehalkı İşgücü Anketi Sonuçları (www.tuik.gov.tr Erişim 18.07.2018).

Türkiye İstatistik Kurumu (2018b), Tanım ve Kavramlar, (http://www.tuik.gov.tr/MicroVeri/Hia_2011/turkce/metaveri /tanim/index.html Erişim:18.07.2018).

Türkiye İstatistik Kurumu (2016), 2016 Hanehalkı İşücü Anketi Mikro Veri Seti.

Yıldız, Doğan; Yıldız, Nuran Çakır; Ilgaz, Yavuz; Güneş, Mehmet Şamil ve Yıldız, Dursun (2017), Su Politikaları Derneği, Türkiye'deki Tarımsal İşücünün Demografik ve Yapısal Dönüşümü Projesi Ön Raporu, Rapor No: 3, Ankara. 